\title{
Analysis of the situation of the Euphrates-Tigris-Shatt Al Arab river system and possible solutions of the devastation of the ecosystem
}

\author{
Matija Kordić, Miloš Milanković \\ University of Belgrade, Faculty of Mining and Geology, Department of Hydrogeology; Đušina 7, Serbia; \\ e-mail:matijakordic@rocketmail.com
}

(C) 2016 Authors. This is an open access publication, which can be used, distributed and reproduced in any medium according to the Creative Commons CC-BY 4.0 License requiring that the original work has been properly cited.

International waters are the most problematic area of water management because there comes to a collision of rights between the riparians, and the most complicated is the problem of trans-boundary rivers (Stevanović 2011). The Euphrates-Tigris-Shatt $\mathrm{Al}$ Arab river system is the largest water resource in the Western Asia with a topographic catchment of more than $900,000 \mathrm{~km}^{2}$ from the Taurus-Zagros Mountain Range to the Persian Gulf and is populated by around 54 million people. The riparians: Turkey, Syria and Iraq have different views on the resources of these rivers. Turkey doesn't agree with the term "sharing waters". They see it as inadequate. For them the Euphrates is a trans-boundary river that is under their sovereignty as long as it is within its territory. Iraq and Syria take it as an "international river" that should be treated as a shared entity. According to Turkey the Euphrates and Tigris form a single water basin, but Iraq and Syria consider them as two separate basins (UN-ESCWA and BGR, 2013). Turkey says that in order to reach an agreement on allocation, negotiations should include all available water resources, but Syria and Iraq disagree. At the 1997 UN Convention on the Law of Non-navigational Use of International Watercourses Turkey was the only Euphrates Basin country that voted against. If they had signed, that could give riparians a veto right over their development plans. In 1987 Damask and Ankara signed a protocol, which guaranteed $500 \mathrm{~m}^{3} \cdot \mathrm{s}^{-1}$ of flow volume in the Euphrates
River to Syria, which was not respected during the filling of Ataturk Dam in 1990.

In 1977 Turkey initiated the South-eastern Anatolia Project (GAP in original) to harness the water of the Tigris and the Euphrates for energy and agricultural production thus providing an economic boost to south-eastern Anatolia by creating 4 million new jobs. The flow of the river has been cut in half by 2010 on the border with Syria and by $2 / 3$ for Iraq since the development of the GAP project. In Iraq this flow reduction is viewed as a national crisis that will have serious consequences (Issa et al. 2014). The project covers an area of $74,000 \mathrm{~km}^{2}$ and is populated by around 7 million people. When completed, there will be 22 dams and 19 hydroelectric power plants on these rivers. The plan is to produce 27,367 GWh of hydroelectric energy per year and to double irrigable farmland to 1.8 million ha (UN-ESCWA \& BGR 2013). Today almost half of GAP has been fulfilled. This led to an increase in salinity and serious changes of the ecosystem and river flow regime. These caused a discord between riparians, NGOs and activists worldwide. International experts think that GAP is going to consume more than 50\% of the Euphrates and about $14 \%$ of the Tigris. To verify this view, two periods of monitoring were selected. The first period is from 1938-1974 and it represents the natural flow of the Euphrates River before the construction of the Keban Dam in Turkey and Lake Assad in Syria and 
the second is from 1974-1998 as the first phase of the evolving infrastructure on the Euphrates basin. The average flow was measured in Jarablat (Syria) and for the first period is around $950 \mathrm{~m}^{3} \cdot \mathrm{s}^{-1}$ and for the second around $800 \mathrm{~m}^{3} \cdot \mathrm{s}^{-1}$, than Hit (Iraq) decreased from $970 \mathrm{~m}^{3} \cdot \mathrm{s}^{-1}$ to $720 \mathrm{~m}^{3} \cdot \mathrm{s}^{-1}$ and Hindijah (Iraq) from $630 \mathrm{~m}^{3} \cdot \mathrm{s}^{-1}$ to $470 \mathrm{~m}^{3} \cdot \mathrm{s}^{-1}$ (UN-ESCWA \& BGR 2013). We can see a pattern and a decrease in river flow volume by around $150 \mathrm{~m}^{3} \cdot \mathrm{s}^{-1}$. Of course, regulation of the Euphrates can protect downstream countries from floods and droughts. The effects of water pollution are mostly visible downstream in Syria because Turkey diverts water from the main course of the Euphrates at Lake Ataturk. The water goes through the Urfa tunnels to the Urfa-Harran agricultural area in the upper Jallab/Balikh and Khabour sub-basins. The return flows from irrigation are large in quantity but poor in quality and they enter Syria mostly through the Jallab River near Tell Abyad and enter the Euphrates through the Balikh River around $200 \mathrm{~km}$ from the Syrian-Turkey border. This shows us why the Euphrates water quality has remained almost unaffected by the agricultural development in Turkey on the Syrian-Turkey border.

There should come to a conjoined look from the riparians on the rights of the ecosystem and the serious damage that is being done to it and the legal obligations of the riparians between themselves, for the sake of the greater good. This is extremely difficult especially now with the rising political problems between Turkey and Syria. International experts in all fields relevant to this problem should meet and discuss the matter, and enforce laws that will stick and solve the issue. The most important issue should be the environment but we should not look the other way for the needs of the riparians and their development too. So very important would be research and evaluation of the potential of all available resources and their combined usage. There should be a good monitoring network of the underground and surface waters and calculation of the regime, balance and reserves and the amounts of water that is needed by riparians, and determining the connection of overall water flow because of the circulation of pollution. Also, an assessment of geothermal potential of the area and its possible usage considering the North and East Anatolian Fault Zone should be made. For example, for the production of electricity solar or geothermal energy could be used, as well as the energy of the wind and the energy of biomass should be utilised, separately or concurrently. If there are underground waters available, a variety of methods could be used, such as "AGRONET" and drip irrigation technique to decrease the usage of surface waters and their pollution. Polluted waters could be used for energy production by constructing a hydroelectric power plant in the area where polluted waters are flowing and there could also be a water treatment plant erected. Polluted waters should be monitored and diverted into one watercourse, which should be controlled by a hydro-isolator securing the ground beneath and on the sides of this new course.

\section{REFERENCES}

Issa I.E., Al-Ansari N.A., Sherwany G. \& Knutsson S., 2014. Expected Future of Water Resources within Tigris-Euphrates Rivers Basin, Iraq. Journal of Water Resource and Protection, 6, 421-432, [on-line:] http://dx.doi. org/10.4236/jwarp.2014.65042 [access: January 2016].

Stevanović Z., 2011. Menadžment podzemnih vodnih resursa. Faculty of Mining and Geology, Belgrade.

UN-ESCWA \& BGR (United Nations Economic and Social Commission for Western Asia; Bundesanstalt für Geowissenschaften und Rohstoffe), 2013. Inventory of Shared Water Resources in Western Asia. Beirut. 